University of the Pacific

Scholarly Commons

2010

\title{
Perelman's Theory of Argumentation and Natural Law
}

Francis J. Mootz III

Pacific McGeorge School of Law

Follow this and additional works at: https://scholarlycommons.pacific.edu/facultyarticles

Part of the Jurisprudence Commons, and the Legal History Commons

\section{Recommended Citation}

Francis J. Mootz III, Perelman's Theory of Argumentation and Natural Law, 43 Philosophy and Rhetoric 383-402 (2010).

This Article is brought to you for free and open access by the McGeorge School of Law Faculty Scholarship at Scholarly Commons. It has been accepted for inclusion in McGeorge School of Law Scholarly Articles by an authorized administrator of Scholarly Commons. For more information, please contact mgibney@pacific.edu. 


\section{G Perelman's Theory of Argumentation and Natural Law}

Francis J. Mootz III

Chaim Perelman resuscitated the rhetorical tradition by developing an elegant and detailed theory of argumentation. Rejecting the single-minded Cartesian focus on rational truth, Perelman recovered the ancient wisdom that we can argue reasonably about matters that admit only of probability. From this one would conclude that Perelman's argumentation theory is inalterably opposed to natural law, and therefore that I would have done better to have written an article titled "Perelman's Theory of Argumentation as a Rejection of Natural Law."

However, my thesis is precisely that Perelman's theory of argumentation connects to the natural law tradition in interesting and productive ways. Perelman referred to natural law in a number of his essays as an example of the excessively rational focus that he sought to correct with his theory of argumentation, but he also noted the power of natural law claims in legal argumentation. To my knowledge, he never offered a detailed account of the connections between his theory of argumentation and natural law. However, Perelman's deep and abiding concern with justice suggests that he could not help but be interested in lines of argumentation that challenge positive laws from some other standpointthat, in some manner, he must embrace some elements of the natural law tradition.

Philosophy and Rhetoric, Vol. 43, No. 4, 2010

Copyright (C) 20I0 The Pennsylvania State University, University Park, PA 
I wish to outline the ways that a natural law account can fit with Perelman's theory of argumentation in order to address an ontological crisis that grips contemporary legal theory. Steven Smith (2004) has persuasively described "law's quandary" now that legal practice purports to be divorced from the natural law contexts in which it developed. Smith provocatively contends that there is "at least a strong prima facie case that modern legal discourse is operating in a sort of 'ontological gap' that divides our explicit or owned ontological commitments (which preclude us from recognizing the reality of 'the law' [that stands distinct from empirical legal practices]) from the ontological assumptions not only implicit in but essential to our discourse and practice (which seem to presuppose the reality of 'the law')" (I994, 63). ${ }^{1}$ In a similar vein, Peter Goodrich describes the plight of contemporary legal theory with concise accuracy, observing that we have abandoned natural law foundations originally constructed in ecclesiastical venues only to find that the project of developing a secular legal language capable of transforming the management of social conflict into questions of technical rationality is doomed to failure (1996, I60-6I).

I contend that by working through a conception of natural law that fits with Perelman's philosophy of argumentation we can find a promising way to address law's ontological crisis. The philosophy of the new rhetoric is a rich resource for describing the ontological space in which law operates and also for providing normative guidance to those engaged in legal practice.

\section{THE NATURAL LAW TRADITION}

The term "natural law" generally calls to mind a philosophical account that bloomed in ancient Rome, was absorbed into the Christian tradition, reached full expression in Aquinas, and then was secularized and rationalized as a philosophy of natural rights. Cicero offered a succinct definition of pre-Christian natural law based on the Stoic tradition, arguing that natural law is universal, eternal, and unchanging and that these characteristics of reality follow from the fact that natural law is authored and administered by a deity.

True law is right reason in agreement with Nature; it is of universal application, unchanging and everlasting.... [W] need not look outside ourselves for an expounder or interpreter of it. And there will not be different laws at Rome and at Athens, or different laws now and in the future, but one eternal and unchangeable law will 
perelman's theory of argumentation and natural law

be valid for all nations and for all times, and there will be one master and one ruler, that is, God, over us all, for He is the author of this law, its promulgator, and its enforcing judge. (I928, 3.22.33)

Cicero's account was easily accommodated to Christian principles that were embraced and propagated by the Roman Empire. Centuries later, Aquinas differentiated eternal law, natural law and positive law, arguing that God's divine will is beyond our ken but that we are capable of determining the conditions under which humans flourish through use of our reason because, to borrow St. Paul's words, the natural law has been written in our hearts. ${ }^{2}$

Following centuries of war and violence waged on behalf of religious belief, Enlightenment scholars sought to ground the persistent demand for human rights in univocal reason rather than a religious cosmology. In this account, human nature gives rise to certain moral precepts rather than a lawgiving deity; more precisely, the integrity and intrinsic worth of human life gives rise to a variety of moral dictates. This shift in emphasis is noted in the term "natural rights," which a person bears, as opposed to "natural law," to which a person is subject.

Most recently, Germain Grisez, John Finnis, and Robert P. George have argued for a "new natural law" that purports to rejuvenate Aquinas's approach in terms that are suitable to our secular and rationalist age. Put simply, they contend that a number of incommensurable human goods simply are given as elements of human flourishing and that these human goods provide a determinate basis for ethical decision making through the exercise of a noncalculative and nonutilitarian practical reasoning.

Theories of natural law reflect critical accounts of the constitutive aspects of the well-being and fulfillment of human persons and the communities they form. The propositions that pick out fundamental aspects of human flourishing are directive (that is, prescriptive) in our thinking about what to do and what to refrain from doing (our practical reason) - that is, they are, or provide, more than merely instrumental reasons for action and self-restraint (George 2007, 55; Finnis 2005).

George emphasizes the chastened character of the "new natural law" by rejecting the idea that judges may directly access its principles in deciding cases; rather, positive law always imperfectly implements natural law, and therefore a commitment to the rule of law is a critical feature of modern constitutional democracies (2007, 7I-75).

This long-standing, but constantly evolving, tradition of natural law thinking does not easily connect with Perelman's theory of argumentation 
for the simple reason that genuine argumentation plays no role in the existence or elaboration of this tradition. The positing of an abiding criterion that exists outside of time or place leaves no room for argumentation; instead, there is simply validity or nonvalidity. Even the "new natural law" is at odds with Perelman's philosophy because it presumes that there are correct answers to moral questions-even though people acting in good faith can disagree about which answer is correct-and also insists that reaching the correct answer is a matter of refining our abilities to reason practically. For example, Anthony Lisska accuses Finnis's "new natural law" of promoting the exercise of theoretical reason in the guise of practical reason (1996, 156). As I explain, Lisska's reconstruction of Aquinas's philosophy in terms of Aristotelian practical reasoning provides a plausible theoretical starting point for conceiving natural law in terms of Perelman's theory of argumentation.

Given its historical trajectory, it should come as no surprise that Perelman roundly criticizes natural law. He rejects the secular, rationalist incarnation of the tradition because it presumes that reason can determine not only what is true in the world of empirical fact but also what is just in the social world (1980, 29-32, 42-44, I3I). His friend and colleague Mieczyslaw Maneli argues that the new rhetoric rejects any traditionalist reliance on a "natural" state of affairs (1986, 36I-62). As Perelman notes, the traditional approach to natural law continually runs aground on the shoals of experience, as demonstrated by the fact that reason has failed to settle debates regarding justice that reach back at least as far as Sophocles (1980, 165). ${ }^{3}$ He concludes that justice is not univocal; instead, it always requires making choices between justifiable tenets that are in conflict. Law must operate in the realm of the reasonable as well as the rational if it is to do justice.

However, Perelman's philosophy also is deeply indebted to Aristotle, and Perelman recognizes that there may be room for a very different understanding of natural law by drawing on Aristotle. In a dictionary entry on the term, Perelman cautions that combining two polysemic words such as "nature" and "law" yields myriad definitions, and so one must think contextually and historically rather than conceptually (Foriers and Perelman I974, I3-I4). Aristotle offers a counterpoint to modern rationalist conceptions of natural law because he was too wedded to the necessity of an equitable leavening of the law to endorse a thoroughly rationalized approach to legal practice. In response to a question at a seminar, Perelman criticized the alignment of natural law with the "rational"-regarded in terms of the 
perelman's theory of argumentation and natural law

mathematical model of moral reasoning-but he emphasized that there was a line of thinking from Aristotle to Aquinas that embraced a more flexible account. "I don't see either Aristotle or Thomas Aquinas saying as Grotius says, that there are eternal laws of justice, just as eternal as the laws of mathematics. It is impossible" (I979a, 22I). As Jan Broekman summarizes, "Natural law and positive law are both historical and subject to change. It is precisely this dimension that defines the inquiry of Perelman" $(1986,383)$. This gesture by Perelman toward the classical understanding of natural law as a feature of the interplay between the hypothesized rational legal system and the reasonable resolution of specific cases provides the starting point for my inquiry.

I use the term "natural law" generally to refer to the tradition of natural law thinking, but in this article I propose a new understanding of natural law. The term "natural law" combines two elements: nature and law. I argue that the "nature" under consideration is human nature-more specifically, our nature as finite, hermeneutical, and rhetorical beings. The "law" to which I refer is not given in the natural world nor promulgated by a deity; rather, it is the social activity of legal regulation. I conclude that "natural law" is best understood as a "naturalized rhetoric," by which I mean that the manner in which we engage in legal regulation is rooted in our interpretive and rhetorical nature. Defined in this manner, natural law fits with Perelman's theory of argumentation, although it is necessary to draw these connections very carefully.

\section{PERELMAN'S THEORY OF ARGUMENTATION AND NATURAL LAW}

There are at least three different ways to think about natural law in conjunction with Perelman's theory of argumentation. First, we can regard natural law as a line of argument, a related family of commonplaces that we find impossible to ignore, despite our overt positivist commitments. Second, we might connect Perelman's contested (and often misunderstood) idea of a "universal audience" to the natural law tradition. Finally, and most radically, we might think of natural law in more far-reaching theoretical terms by conceiving Perelman's philosophy as propounding a "naturalized rhetoric." By connecting with the natural law tradition in these multiple ways, Perelman's theory of argumentation demonstrates robust affinities with natural law. In this short article I can only adumbrate these three lines of inquiry. 


\section{Natural Law as a Commonplace}

Perelman recognized that natural law plays an important role in legal argumentation, even if we reject the claim that there is an objective structure of justice that can be understood through the use of reason:

The idea of natural law is also misconceived when it is posed in ontological terms.... Natural law is better considered as a body of general principles or loci, consisting of ideas such as "the nature of things," "the rule of law," and of rules such as "No one is expected to perform impossibilities," "both sides should be heard"-all of which are capable of being applied in different ways. It is the task of the legislator or judge to decide which of the not unreasonable solutions should become a rule of positive law. Such a view, according to Michel Villey, corresponds to the idea of natural law found in Aristotle and St. Thomas Aquinas-what he calls the classical natural law. (I979b, 33-34)

The dialectic of the reasonable and the rational in law shows the need for a more flexible understanding of natural law as something other than a rational construct that is timeless and universal (Perelman I979b, 120-22).

Perelman's analysis of the natural law tradition as a collection of commonplaces exemplifies how rhetorical exchanges working from commonplaces contain a critical bite. He cites the decision by the Allies to justify the Nuremberg trials with appeals to natural law as a concession to the fact that the demands of justice exceed the capacity of positive law (1979b, 104). Even if the history of natural law thought is marked by authoritarian and ideological overtones, Perelman does not regard the tradition as a "mistake" that should - or can-be exorcized from our vocabulary. He effectively strips natural law precepts of their inauthentic claims to eternal and universal validity and urges legal theorists and practitioners to utilize the principles as vital (indeed, unavoidable) resources for introducing innovation and for critiquing existing legal relations.

Perelman's approach recalls Aristotle's advice about how to argue against application of a written law that is against one's interest when it is read literally rather than in an effort to effectuate the purpose of the law. In the Rhetoric, Aristotle recommends arguing that following the written law slavishly would do an injustice, quoting Antigone's pleas as a basis for this line of argument. He suggests one should argue this point first by 
perelman's theory of argumentation and natural law

observing that "it is evident that if the written law is contrary to the facts, one must use common law and arguments based on fairness as being more just." Next, he says, one should point out that "to use 'best understanding' is not to follow the written law exclusively" and "that fairness always remains and never changes nor does the common law (for it is in accordance with nature) but written laws often change" (I99I, IIO). Aristotle emphasizes that the advocate should argue that not all written laws are just, and so the person seeking justice should conform to the unwritten law (I99I, 66-74).

Tony Burns (2002) explains why Aristotle includes this line of argumentation in the Rhetoric. First, Burns argues that Aristotle miscasts Sophocles as a defender of a universal and eternal natural law. It is more likely that Antigone is appealing to tradition-bound and parochial religious custom rather than invoking abstract and eternal principles. In other words, Antigone invokes a premodern natural law argument that too often is lost in our rationalist readings of Aristotle, providing additional support for the idea that the "natural law" is a confused concept that has been invoked as part of arguments within differing contexts over the millennia.

More important, Burns contends that Aristotle did not endorse this line of argument, although by including it in the Rhetoric he acknowledged that these types of argument-most vividly advanced by sophistic challenges to slavery as an "unnatural" practice- had found currency among his contemporaries $(2003,28-35) .{ }^{4}$ To the extent that Aristotle eventually did endorse natural law arguments, Burns contends that he did so in order to justify the status quo against radical attacks (2003, 34-35). Burns explains:

Aristotle's treatment of the concept of natural justice or law ... in the Nicomachean Ethics, in striking contrast to what he says about natural law arguments in the Rhetoric, might be seen as a classic illustration of such a rhetorical manoeuvre. The irony of Aristotle's suggestion that it is his radical political opponents such as Alcidimas who employ the concept of natural law in a merely rhetorical manner whereas he himself employs the same concept in the pursuit of objective ethical truth is readily apparent-especially (but not only) to those of a Nietzschean or poststructuralist philosophical persuasion. $(2003,35)$

Natural law has a complex valence in Aristotle's usage, but Perelman would certainly conclude that these different uses of natural law by Aristotle follow from the fact that it is an essentially contested concept 
that is closely connected to justice. If natural law is an ontological feature of the world, it must be the case that when both parties in a debate invoke natural law one of them must be wrong. However, when natural law is understood as a commonplace from which one may argue many points in different ways, one must regard it as a supple and polysemic concept that does not yield singular answers to social and legal disputes. Even the highly rationalistic notions of natural rights that arose in the Enlightenment period can be viewed as lines of critical argumentation against the status quo that proved to be incredibly productive rhetorical strategies even though they lacked the certainty an ontological backing could provide. As Michel Foucault reminds us, critique might be seen as "the art of not being governed quite so much," and he highlights the historical emergence of natural law arguments in favor of human rights as one of three historical points in the emergence of critique as an element of the Enlightenment $(2007,45)$. Natural law can be seen as an ideological commitment to the status quo or as liberating critique, which is precisely its importance as a line of argumentation.

Lawyers encounter examples of the polysemic character of commonplaces on a daily basis; this is the source of the energy and innovation of legal argumentation. Consider the issues raised by the collection of policies and practices known collectively as "affirmative action." The law is quite clear that states may not deny to any citizen equal protection under the law. But what does this commonplace mean in the context of determining which employees will be promoted in a certain workplace? Does equality mean subjecting every employee to the exact same testing criteria, or does it mean assessing the merits of each individual employee to perform the job functions while also attending to the effects of past discrimination on certain employees' ability to compete according to supposed neutral criteria? It is a curious, but not altogether uncommon, feature of legal practice that opposing sides in a contentious legal dispute can appeal to the same legal principles and rules in support of their respective positions. These localized doctrinal disputes reflect the same dynamic that has been at work in the use of natural law arguments since the dawn of Western civilization.

\section{Natural Law as the Construction of a Universal Legal Audience}

Perelman's development of the ancient attention to audience is one of his signature contributions to rhetorical theory. Noting that the audience envisioned by the speaker "is always a more or less systematized construction," 
perelman's theory of argumentation and natural law

Perelman places emphasis on the speaker's goal of creating her audience in the course of addressing it (Perelman and Olbrechts-Tyteca 1969, I9). In some circumstances, a speaker will aspire to more than persuading the audience to which the speech is immediately directed and will claim to offer reasons that would be convincing to all reasonable persons. "This refers of course, in this case, not to an experimentally proven fact, but to a universality and unanimity imagined by the speaker, to the agreement of an audience which should be universal, since, for legitimate reasons, we need not take into consideration those [who] are not part of it" (Perelman and Olbrechts-Tyteca I969, 3I). Speakers construct a universal audience not only to shape their discourse but also to entreat the concrete audience before them-which "can never amount to more than floating incarnations of this universal audience" (Perelman and Olbrechts-Tyteca I969, 3I)—to imagine themselves as part of such an audience. As Perelman emphasizes, the actual audience helps to validate the speaker's construction of the universal audience, even as the universal audience serves as a check on the parochial concerns of the actual audience (Perelman and Olbrechts-Tyteca I969, 35).

All lines of argumentation are shaped to the audience to which they are addressed, and natural law arguments are no different. I believe that it makes good sense to regard natural law arguments as addressing a particular audience in their capacity as a contingent example of a hypothesized universal audience. When some sophists argued that slavery was an affront to the natural dignity and equality of all men they appealed to a specific Greek audience rooted in customary practices of slavery, but they sought to provoke this audience to recognize its membership in a broader universal audience. Arguing that slavery is a violation of universal norms that are part of the structure of reality does not call for an investigation of the natural world; rather, it calls for a reconfiguration of the self-understanding of the audience.

As a lawyer and law professor, I have no doubt that natural law arguments (even if not expressly characterized as such) are ubiquitous and perhaps unavoidable in legal practice. If we agree with Perelman that there is no abiding structure of reality that grounds these arguments ontologically, we must seek to understand them by exploring the character of the audience that the legal orator seeks to construct and the manner by which the orator seeks to motivate an actual audience to act in response to them. I regard it as impossible to carry out this task without employing a conception of the universal audience, which suggests that the notion of the 
universal audience is critical to Perelman's philosophical clarification of legal argumentation, a practice that he regarded as exemplary for moral argumentation (I980, II4-I9, I46, I74). This leads me to conclude that the idea of natural law claims as commonplaces that seek resonance with an audience inspired to reconstitute itself as the universal audience resides at the center of Perelman's theory of argumentation and is not just an obscure detail in Perelman scholarship.

By exploring natural law arguments made within the context of the legal system we can avoid some of the many misunderstandings that have arisen from Perelman's use of the term "universal audience" to refer to a hypothesized audience of all reasonable persons to whom a philosophical claim to truth is addressed. A natural law argument is directed to a universal audience for whom the actual audience-whether a jury, judge, or appellate panel-serves as a stand-in. But this is not to say that the audience is hypothesized to be generically "rational" or "philosophical." Claims in this setting are peculiarly legal in nature and are best paraphrased as "No reasonable person seeking to implement the values of our legal system could conclude that slavery is legitimate, notwithstanding our custom and written laws to the contrary." Arguments traditionally couched in natural law terms are not arguments made to a timeless and decontextualized rational being; rather, these arguments are designed to provoke the actual audience to rise above their parochial interests and to conceive of themselves as empowered to articulate truth, justice, and other confused notions in a manner that all members of the community should find persuasive. Using the terminology of contemporary rhetorical criticism, we can say that natural law arguments address a particular audience of intended readers with the goal of invoking an idealized (universal) audience (see Selzer 1992).

Trial lawyers emphasize the importance of developing a "theory of the case," which is to say that they try to construct a narrative that the jury will endorse as its own recounting of what happened and what should be done. The "theory of the case" is in fact a factual narrative rather than a theoretical construct. The goal is to persuade the jury that justice demands a verdict in favor of one's client; literally, the facts are presented so that they appear to speak for themselves. Perhaps the most famous, and most mimicked, theory of the case was offered by veteran trial lawyer Johnnie Cochran in his defense of O. J. Simpson for the murder of his ex-wife and her companion. Although the rhyming cadence of "If it doesn't fit, you must acquit" provoked laughs when repeated by late-night comedians, Cochran employed a powerful rhetorical device to summon the jury to 
perelman's theory of argumentation and natural law

assume its role as the guarantors of justice. The evidence against Simpson was powerful and comprehensive, and yet the prosecution's case was filled with various holes, inconsistencies, and gaffes. Cochran's theory of the case was simple: despite overwhelming forensic evidence, the government's actions and representations evidenced a malicious, or at least incompetent, approach to the prosecution that should not be tolerated by a jury empaneled to do justice.

We can see in the everyday practice of trial lawyers the rhetorical call for a specific audience to act as a universal audience. The entire trial process is suffused with procedural elements that permit the competing rhetors- the opposed lawyers - to construct the audience they will address in the closing argument. From jury selection, to the narrative drama of the presentation of the evidence, to the formulation of jury charges, and through the closing arguments, the trial is a sustained effort to construct the jury in such a way that it assumes its role as an incarnation of the universal audience that rises above the immediacy of the individual concerns of the jurors. In $A$ Theory of the Trial, Robert Burns argues that a trial structures competing linguistic practices and performances to enable the trier to make practical judgments about what is to be done in response to complex and competing accounts of facts and norms (I999). This leads Burns to characterize judgment as the "strife" of competing claims to truth (I999, I8I-82). The advocates call on the jury to act as a universal audience capable of working through this unavoidable strife in reasonable fashion.

The jury responds to the competing narratives first by determining the important issues at stake and then by resolving them in a practical manner that reaffirms the integrity of both general principles and the specific factual circumstances. Burns concludes:

I have argued that a great advantage of the contemporary trial is its internal complexity, comprising empirical, moral, political, and strictly "legal" language and values. It is sufficiently flexible to allow, indeed to require, that the jury determine what the most important aspect of the case is....

... The trial's constitutive rules and practices allow for delicate choices about the inevitable metalevel questions woven into the trial's different linguistic practices. If these incommensurable spheres exhaust our social perspectives, if there is no Platonic perspective from which one might determine which sphere is ultimately dominant, from which (partial) perspective ought the jury to decide 
which perspective is the right one? The answer seems to me clear. The jury decides the metalevel questions from the perspective of commonsense morality, rigorously applied, criticized, and sometimes challenged by the devices of the trial. The existence of such a forum is a challenge to any form of social ordering that cannot justify its distinctive principles in the language of ordinary morality. $(1999,239,244)$

The theory of the case, the artful construction of past factual events during the trial, is more than a base appeal to individual jurors to display their moralistic biases. The jurors are challenged to act in concert, after deliberation, to repair a breach of social ties. Sitting in judgment over the strife of incommensurable claims, they collectively act as a transitory incarnation of the universal audience.

\section{Naturalizing Rhetoric}

There is a final, and more radical, sense in which we can connect natural law with Perelman's theory of argumentation. I term this approach, "naturalizing rhetoric." This is a potentially misleading term, and so I want to unpack my meaning carefully. As used in contemporary philosophical discourse, "naturalism" refers generally to a philosophy that sees itself as clarifying the empirical dimensions of reality rather than engaging in speculative metaphysics. The assumption is that nature is just empirical reality, subject to scientific investigation as supplemented by philosophical reflection. I use the term "naturalized rhetoric" as a provocation to challenge this prejudice: we "naturalize" rhetoric when we regard human "nature" as a deeply rhetorical condition. Simply put, it is our persistent human condition to continuously recreate ourselves and our society through rhetorical exchanges with others. A naturalized rhetoric embraces the paradox that nonessentialism is essential to our being, that we can find a foundation for reflection in antifoundationalism. ${ }^{5}$

A naturalized rhetoric has both explanatory and normative force. On the one hand, a naturalized rhetoric underwrites Perelman's theory of argumentation by emphasizing that it is an affirmative account of our nature as reasoning beings rather than a reluctant concession to the limitations of our rational capacity. Perelman is less vigorous in his critique of Cartesian rationalism than $\mathrm{Vico}$, who argued against the incipient rationalism of the 
perelman's theory of argumentation and natural law

Western tradition by defending the priority of rhetoric and its connections to our imaginative capacities and the metaphoric structure of human understanding (Mootz 2008b; Mootz 2009). By naturalizing rhetoric in the humanist tradition exemplified by Vico we can elaborate the ontological claims that subtend Perelman's theory of argumentation.

Hans-Georg Gadamer's philosophical hermeneutics performs the necessary task of providing an ontological grounding of Perelman's rhetorical philosophy in a manner that connects with Vico's more radical rhetorical insights. The centerpiece of Gadamer's account of the nature of human understanding is the metaphor of a conversation that yields an ongoingwhich is to say a never completed-fusion of horizons. If our nature is deeply hermeneutical, it is also deeply rhetorical. We engage others rhetorically; we experience this engagement hermeneutically. Gadamer provides guidance in the face of "Cartesian anxiety" by providing an ontological account of the social nature of understanding (Bineham 1995). Perelman's description of rhetorical moves can be misinterpreted as a relativistic response to the Cartesian model of knowledge, but Gadamer's ontological account grounds Perelman's rhetorical philosophy in a way that prevents this misreading (Mootz 2006, 30-32). In other words, Gadamer's philosophical hermeneutics ensures that we appreciate Perelman's work as a description of the human condition, not as a handbook of argumentative strategies.

Important normative implications follow from a naturalized rhetoric. If it is our nature to be rhetorical, an ethical system oriented toward promoting human flourishing would require that we ensure the social and legal context for the development of this capacity. This recognition would not lead to specific policy prescriptions nor provide definitive answers to specific legal dilemmas, but it would generally point us in the direction of maximizing human communication and exchange. Moreover, a naturalized rhetoric suggests a basis from which we might approach one of the central questions in rhetorical theory - whether there is a basis for distinguishing "good" rhetoric from "bad" rhetoric-in a more productive manner.

Jeffrey Maciejewski $(2005,2006)$ makes just this claim by connecting the basic good of social life to the natural fact that rhetoric is necessary to fashion a community. Although overly wedded to nonrhetorical features of Aquinas's natural law philosophy, Maciejewski aligns himself with the notion of an evolving human nature that is rhetorically secured in social intercourse. He properly concludes that there is a natural rhetoric essential to the development of the person. 
When examined more acutely using a moral theory attuned to human behavior such as natural law, it seems that declaring persuasion immoral as a violation of autonomy belies the human penchant for employing rhetoric as part of living in society. As rhetoric services reason, which in turn services the dispositions, it can be seen as a natural, morally praiseworthy concomitant of the exercising of reason which helps to reveal the potentiality of reason itself. Moreover, I believe it possible to refer to such rhetoric as "natural." (2005, 256)

However, when exploring these themes it is crucial to avoid the temptation to essentialize our rhetorical nature by supposing that it includes more substantive agreement on shared norms than can be secured in dialogue and argumentation. In other words, it is always illegitimate to recognize our rhetorical nature but then to prescribe certain "natural law" claims that must be accepted by all rational persons and that therefore can be coercively imposed.

Perelman's cautions about the dangers of invoking the universal audience speak to these potential abuses of natural law claims. Perelman warns of the danger of elitism that results in characterizing dissenters as irrational or heretics or that leads the speaker to constrict the actual audience to a small vanguard that already agrees with the claims put forward (Perelman and Olbrechts-Tyteca 1969, 33-34). These ideological tendencies are closely associated with natural law argumentation through the ages, but it is precisely by naturalizing rhetoric that we have the best chance of avoiding this misuse of natural law commonplaces. By recognizing that it is our nature to be rhetorical, and that the variety of legal systems rest on this naturalized rhetoric rather than on an objective state of affairs that can be discerned by reason alone, we can understand how natural law argumentation works to construct a universal audience through rhetorical means.

I am not writing on a completely blank slate in legal theory to suggest this reading of the natural law tradition. Even the resolute analytical legal positivist, H. L. A. Hart, concedes that it made sense to acknowledge that there is a minimal natural law requirement that shapes a legal system in light of our human nature and the bare need for survival (1994, 193-200). Hart argues that the nature of human existence-our vulnerability to each other, our approximate equality in endowments, and our not being either wholly altruistic or evil-provides the context in which certain sociolegal conditions must be present to permit survival. Hart suggests that this recognition shows a way to do justice to both the natural law and positive 
perelman's theory of argumentation and natural law

law traditions: "We shall no longer have to choose between two unsuitable alternatives which are often taken as exhaustive: on the one hand, that of saying that this is required by 'the' meaning of the words 'law' or 'legal system,' and on the other, that of saying that it is 'just a fact' that most legal systems do provide for sanctions" (1994, 199).

Rather than debating whether sanctions are an essential feature of the concept of legality, Hart suggests that we are better served by regarding them as a "natural necessity" in light of the human condition. Needless to say, this concession has sparked spirited debate. ${ }^{6}$

There are several productive points of reference in recent legal theory that develop alternative accounts of natural law in a manner congenial to my thesis. In contrast to Hart's minimal concession, Lon Fuller argued that moral commitments generated in communicative exchange extend beyond, and sometimes override, the biologically driven struggle to survive (1969, I84-86). In his final response to the criticisms of his proceduralist approach to natural law, Fuller revealed that he was a genuine natural law theorist. Elsewhere I have argued that these brief and overlooked remarks reveal that Fuller is best understood as a proponent of the style of natural law that resonates with Perelman's rhetorical philosophy (I999, 338-45). Fuller's dramatic final plea on behalf of natural law calls for what I have termed a naturalized rhetoric: "If I were asked, then, to discern one central indisputable principle of what may be called substantive natural law-Natural Law with capital letters-I would find it in the injunction: Open up, maintain, and preserve the integrity of the channels of communication by which men convey to one another what they perceive, feel, and desire" (I969, I86). More recently, Lloyd Weinreb (I987, I994) has moved beyond Fuller's tentative suggestion and argued in favor of natural law understood as the effort to work out the normative kosmos in which we find ourselves as creative participants.

The work by Fuller and Weinreb provides excellent starting points in legal theory for understanding the concept of a naturalized rhetoric as a productive development of the natural law tradition. Fuller paid scant attention to these dimensions of his work, providing only a gesture at the end of his career toward this type of analysis. Weinreb has more thoroughly embraced nomos as the ground of natural law, thereby bringing himself within the rhetorical tradition defended by Vico and revived by Perelman. However, Weinreb's approach is on the fringe of American jurisprudential writing; his singular voice has not resonated in a positivist era during which the natural law tradition has waned into virtual irrelevance. Reading Perelman's philosophy as a naturalized rhetoric provides vital context and 
backing for Weinreb's work, permitting more detailed elaborations of the hermeneutical-rhetorical character of legal practice.

\section{CONCLUSION}

We can make significant headway in providing a practical and theoretical response to the ontological quandary facing contemporary legal theory if we reconsider the natural law tradition by connecting it to Perelman's theory of argumentation in the three ways that I have described. Steven Smith's incisive description of law's quandary paralyzes the reader by offering an either-or proposition: either "the Law" refers to something outside legal practice that can direct it, or it is just a nonsensical reference that exposes an ontological gap in which our discourse operates. These unsatisfactory alternatives obscure the fact that the rhetorical appeal to "the Law" is not an appeal to something that exists outside the practice of law. By attending more carefully to legal practice we can explain and justify our references to "the Law" as part of the rhetorical elements of legal practice. Legal practice has historical and normative depth that always vastly exceeds any particular legal argument.

Consider the situation facing lawyers who are litigating a case of first impression regarding enterprise liability for drug manufacturers when the maker of the drug that was ingested by the plaintiff cannot be determined. Lawyers from both sides will argue strenuously that the law requires a verdict in favor of their client, which means that there is an appeal to something beyond the equities attendant to the particular case before them. The "beyond," however, just is the historical trajectory of the ongoing practice brought to bear on the case before the parties. Lawyers cannot generate a uniquely correct result for the case at hand by means of dialectical reasoning (despite the rhetorical conventions of legal argumentation that purport to accomplish this impossible feat), but in their appeals to the legal tradition they can generate plausible arguments for a rhetorical elaboration of what "the Law" requires in the case at hand.

In Perelman's account, "the Law" is best conceptualized as a set of commonplaces from which one can draw in making an argument in a particular case and by which one invokes a universal audience that is competent to do justice (I980). The topoi that form "the Law" are real and provide guidance, even if they cannot resolve specific legal disputes definitively. Referring to "the Law" is just to make a general reference to the topoi from which one can argue for a specific result; consequently, "the Law" is neither empty nor a means of answering legal questions from the "outside." 
perelman's theory of argumentation and natural law

We invoke "the Law" as a call for a response from the audience. The call asks the audience to respond by assuming the role of an idealized audience that is competent to do justice. The ubiquitous commonplaces of natural law argumentation in contemporary legal practice are not simply moves within the logic of doctrinal elaboration; rather, these commonplaces are focused on shaping the audience's self-understanding. Natural law commonplaces serve an epideictic role as much as a forensic or logical role, and Perelman grasped the significance of this role in his much misunderstood, and much maligned, notion of the universal audience.

Finally, the activity of appealing to "the Law" is a feature of our nature as hermeneutical and rhetorical beings, a nature that we can explore by pursuing a naturalized rhetoric. Perelman does not simply catalogue arguments that may be deployed in rhetorical situations; he provides a window to human nature. Perelman is best read as pursuing a naturalized rhetoric, and from this understanding important implications for the natural law tradition follow. By reading Perelman in this more radical manner we not only recognize the full scope of his ingenuity and originality but also make headway in one of the most important debates in political and legal philosophy.

Smith has argued that law is in a metaphysical quandary, separated from its natural law roots with no viable substitute to sustain legal legitimacy. With Perelman's guidance, we find a natural law solution to law's quandary in the account offered by contemporary rhetorical philosophy, even if it is very different from the traditional natural law accounts that shape Smith's anticipation of a suitable resolution of the quandary. Perelman's theory of argumentation provides a way to resuscitate natural law theorizing while at the same time moving firmly beyond the false certainties that Perelman knew only impede our quest for justice.

William S. Boyd School of Law University of Nevada, Las Vegas

\section{NOTES}

An earlier version of this article was presented at "The Promise of Reason," convened at the University of Oregon in May 2008. I thank Jim Crosswhite, David Frank, and John Gage for putting together an excellent conference and for inviting me to attend. I extend special thanks to Jim Crosswhite for organizing this symposium and for providing such helpful feedback to me as I developed my talk into an article. I dedicate this article to Jan M. Broekman, dean emeritus of the Faculty of Law at the Katholieke Universiteit Leuven, Belgium, and distinguished visiting professor at Penn State's Dickinson School 
of Law, in gratitude for a vibrant intellectual exchange whose mark extends well beyond this paper and for a warm, personal friendship. Professor Broekman does not necessarily endorse my theme - in fact, he remains quite skeptical about the utility of natural lawnor is he to blame for the deficiencies that remain in my argument.

I. I have reviewed Smith's book in some detail elsewhere (Mootz 2008a).

2. In his letter to the Romans, St. Paul writes: "For when Gentiles who do not have the Law do instinctively the things of the Law, these, not having the Law, are a law unto themselves, in that they show the work of the Law written in their hearts, their conscience bearing witness and their thoughts alternately accusing or else defending them, on the day when, according to my gospel, God will judge the secrets of men through Jesus Christ" (New American Standard Bible 1995, Romans 2:I4-I6).

3. Robert George concedes that the truths of natural law often are obscured by socially constructed ideologies, as when southerners in the antebellum American South defended slavery $(2007,62)$. Hence, his conclusion: "So, if there is a set of moral norms, including norms of justice and human rights, that can be known by rational inquiry, understanding, and judgment even apart from any special revelation, then these norms of natural law can provide the basis for an international regime of human rights. Of course, we should not expect consensus" $(2007,64)$.

4. Burns challenges the conventional attribution to the sophists of radically relativist beliefs, concluding that "at least some of the sophists were not relativists but objectivists so far as questions of ethics are concerned" and that "the critical attitude of this group of thinkers towards the institution of slavery indicates the presence in fifth-century Athens of a universalist, cosmopolitan, rationalist and humanitarian approach to questions of ethics and politics" (Burns 2003, 25, 26). The primary example is Alcidimas,

who maintained that the institution of slavery contradicts rather than conforms to the principle of equity, which is the most fundamental principal of natural justice. This principle states that those who are equal ought to be treated equally in relevantly similar circumstances. The difference between Alcidimas and Aristotle is that Alcidimas took the view that all human beings are by nature equal, and therefore that slavery is ethically unjustifiable, whereas Aristotle did not. $(2002,550)$

5. Naturalizing rhetoric does not rest on theological commitments, but neither is it necessarily at odds with religious belief. John Macquarrie contends that a viable account of natural law can serve as a bridge between faith and morality if it "takes account of the change and development which ... are characteristic not only of man's images of himself but of his very nature and of the world around him" (1991, 232). Macquarrie explains:

But if we acknowledge ... that man's nature is open, and that he is always going beyond or transcending any given state of himself; and if we acknowledge further that this open nature of man is set in the midst of a cosmos which is likewise on the move and is characterized by an evolving rather than a static 
perelman's theory of argumentation and natural law

order; then we must say that the natural law itself, not just its formulations, is on the move and cannot have the immutability once ascribed to it. But what has perhaps more than anything else discredited the natural law concept is the tacit assumption that there was a kind of original human nature to which everything subsequent is an accretion.... Man's very nature is to exist, that is to say, to go out of himself, and in the course of this he learns to take over from crude nature and to do in a human (and humane) way what was once accomplished by blind natural forces (both in man and outside of him) working in a rough and ready manner. (I99I, 24I)

My notion of a naturalized rhetoric would be one manner of dealing with the dynamic reality of man's nature and could be accommodated to religious belief, as Macquarrie suggests, without being dependent on any such belief.

6. Richard Epstein (2005) has argued that we ought to inflate Hart's "natural necessity" to a more robust, yet still libertarian, notion of human welfare. In response, James Allan (2007) argues that it is a mistake to expand Hart's minimalist approach.

\section{WORKS CITED}

Allan, James. 2007. "Is You Is or Is You Ain't Hart's Baby? Epstein's Minimum Content of Natural Law." Ratio Juris 20 (2): 213-29.

Aristotle. 1991. On Rhetoric: A Theory of Civic Discourse. Trans. and ed. George A. Kennedy. Oxford: Oxford University Press.

Bineham, Jeffery L. 1995. "The Hermeneutic Medium.” Philosophy and Rhetoric 28 (I): I-I6. Broekman, Jan M. 1986. "Justice as Equilibrium." Law and Philosophy 5 (3): 369-9r.

Burns, Robert P. 1999. A Theory of the Trial. Princeton, NJ: Princeton University Press.

Burns, Tony. 2002. "Sophocles' Antigone and the History of the Concept of Natural Law." Political Studies 50 (3): 545-57.

- 2003. "The Tragedy of Slavery: Aristotle's Rhetoric and the History of the Concept of Natural Law." History of Political Thought 24 (I): 16-36.

Cicero. 1928. De re publica. Trans. Clinton Walker Keyes. Cambridge, MA: Harvard University Press.

Epstein, Richard. 2005. "The Not So Minimal Content of Natural Law." Oxford Journal of Legal Studies 25 (2): 219-55.

Finnis, John. 2005. "Foundations of Practical Reason Revisited." American Journal of Jurisprudence 50:109-3I.

Foriers, Paul, and Chaïm Perelman. 1973-74. "Natural Law and Natural Rights." In Dictionary of the History of Ideas, ed. Philip P. Wiener, 3:I3-27. New York: Scribner and Sons.

Foucault, Michel. 2007. "What Is Critique?" Trans. Lysa Hoshroth. The Politics of Truth. Ed. Sylvère Lotringer. Los Angeles: Semiotext(e).

Fuller, Lon L. 1969. The Morality of Law. Rev. ed. New Haven, CT: Yale University Press. George, Robert P. 2007. "Natural Law." American Journal of Jurisprudence 52:55-75.

Goodrich, Peter. 1996. Law in the Courts of Love: Literature and Other Minor Jurisprudences. London: Routledge. 
Hart, H. L. A. 1994. The Concept of Law. 2nd ed. Oxford: Oxford University Press.

Lisska, Anthony J. 1996. Aquinas' Theory of Natural Law: An Analytic Reconstruction. Oxford: Oxford University Press.

Maciejewski, Jeffrey J. 2005. "Reason as a Nexus of Natural Law and Rhetoric." Journal of Business Ethics 59 (3): 247-57.

- 2006. "Natural Law, Natural Rhetoric, and Rhetorical Perversions." Proceedings of the American Catholic Philosophical Association 79:173-87.

Macquarrie, John. 199r. "Rethinking Natural Law." In Natural Law and Theology, ed. Charles E. Curran and Richard A. McCormick, 22I-46. New York: Paulist Press.

Maneli, Mieczyslaw. 1986. "Perleman's Achievement Beyond Traditional Philosophy and Politics." Law and Philosophy 5 (3): 351-67.

Mootz, Francis J., III. 1999. "Law in Flux: Philosophical Hermeneutics, Legal Argumentation, and the Natural Law Tradition." Yale Journal of Law and the Humanities II (2): 3II-82.

- 2006. Rhetorical Knowledge in Legal Practice and Critical Legal Theory. Tuscaloosa: University of Alabama Press.

- 2008a. "After Natural Law: A Hermeneutical Response to Law's Quandary." Journal of Law and Religion 9 (2): I-I2.

- 2008b. "Vico's 'Ingenious Method' and Legal Education." Chicago-Kent Law Review 83 (3): I26I-I3O2.

-2009. "Vico and Imagination: An Ingenious Approach to Educating Lawyers with Semiotic Sensibility." International Journal of Semiotics and Law 22 (I): II-22.

New American Standard Bible. 1995. La Habra, CA: Lockman Foundation.

Perelman, Chaï. 1979a. “The Rational and the Reasonable." In Rationality To-day, ed. Theodore F. Geraets, 213-24. Ottawa: University of Ottawa Press.

- 1979b. The New Rhetoric and the Humanities: Essays on Rhetoric and Its Applications. Trans. William Kluback. Boston: Reidel.

- 1980. Justice, Law, and Argument: Essays on Moral and Legal Reasoning. Trans. William Kluback et al. Boston: Reidel.

Perelman, Chaïm, and Lucie Olbrechts-Tyteca. 1969. The New Rhetoric: A Treatise on Argumentation. Trans. John Wilkinson and Purcell Weaver. Notre Dame, IN: University of Notre Dame Press.

Selzer, Jack. 1992. "More Meanings of Audience." In A Rhetoric of Doing: Essays on Written Discourse in Honor of James L. Kinneavy, ed. Stephen Witte, Neil Nakadate, and Roger Cherry, I6I-77. Carbondale: Southern Indiana University Press.

Smith, Steven D. 2004. Law's Quandary. Cambridge, MA: Harvard University Press.

Weinreb, Lloyd L. 1987. Natural Law and Natural Justice. Cambridge, MA: Harvard University Press.

- 1994. Oedipus at Fenway Park: What Rights Are and Why There Are Any. Cambridge, MA: Harvard University Press. 